\title{
Against all odds: Socio-economic and political factors related to female labor force participation and decision making power in Bangladesh
}

\author{
Rouf, Kazi Abdur $\bowtie$ \\ York Center for Asian Research Center (YCAR), York University, Canada (Kaziabdur56@hotmail.com)
}

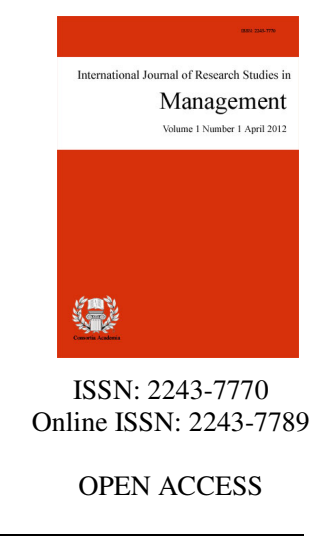

\section{Abstract}

Gender inequality and discrimination is persistent in different socio-economic and political institutions. Women are mainly treated as second sex, sex objects, reproductive agent and their economic contributions to the family, market and state are largely ignored. These discriminations are transferred through the institution of patriarchy, labor force participation and different national and international programs and policy processes. The rigidity and confinement of women within households is experiencing minimal change. A majority of women continue to experience inequalities in different sectors of the society; both in developed and developing countries. However, in terms of gender inequality, female labor force participation is a major factor. This paper reviewed feminist literatures and author personal experiences working with women particularly marginalized women in many countries. The paper examines the interrelating issues of female labor force participation, patriarchy, differential household structures and development policies as they exist in Bangladesh.

Keywords: Grameen Bank; gender inequality; patriarchy; poverty; social reproduction; and women commoditization 


\section{Against all odds: Socio-economic and political factors related to female labor force participation and decision making power in Bangladesh}

\section{Introduction}

The institution of patriarchy is a pervading factor which affects almost all aspects of society including the state, market, community and the family. The continued discrimination of females is maintained by the biases brought about by patriarchy. Examining and making recommendations for changing the operations of this institution, especially as it affects women's economic lives, should contribute towards the overall empowerment of women and gender equality in the context of Bangladesh and in other regions as well. This paper will incorporate the analysis of three books. The first section will describe the summaries of two books: (1) Eradication and the Millennium Development Goals by Naila Kabeer and (2) In Quest of Empowerment: The Grameen Bank Impact on Women's Power and the Status by Ainon Nahar Mizan. The second part will present the issues mentioned above.

\section{Part A: Summaries of the Books}

\subsection{Gender mainstreaming in poverty eradication and the millennium development goals by Naila Kabeer} (2003).

There are eight chapters in 'Gender mainstreaming in poverty eradication and the millennium development goals by Naila Kabeer. The first chapter talks about gender in poverty and the development policies initiated by different international agencies like the World Bank and the United Nations. The reports produced by these two organizations did not place significant emphasis on gender equality and poverty until the Millennium Development Goals (MDGs) 2000. MDGs of 2000 are focused on eradicating extreme poverty and hunger, promoting universal primary education, and promoting gender equality and environmental sustainability. Women were identified as the poorest of the poor in the world and they were usually found to be the majority of the victims of globalization.

Chapter Two focuses on integrating gender into macro-economic analysis. Here the author describes neo-classical economic frameworks in comparison to political frameworks in order to get an understanding of gender and poverty. Before 2000, macroeconomic policies were not gender neutral. Macro economists treated human resources as natural resources. Reproductive work was considered natural to women and regarded as their main goal. Therefore, goods and services produced by women go relatively unnoticed in the economic sector. Women's domestic and reproductive labor is not priced in the market. Naila Kabeer mentions (2003) that there is also an assumption from the macroeconomic perspective that a reduction of men's poverty would automatically help women.

Chapter Three narrates the geography of gender inequality. Institutions play a powerful role in shaping human behavior and give rise to regional patterns in labor force participation and the economic activity of men and women (Kabeer, 1995). Social reproduction creates gender discrimination. Regional differences create various types of kinship relationships, household patterns and gender division of resources. These combine to produce differences in production and reproduction, paid and unpaid wages and domestic and public domains (Ibid, 1993). However, due to patriarchy there are lower rates of female labor force participation and wage differentials between women and men in Bangladesh (Ibid, 1993).

Chapter Four discusses approaches to poverty analysis and its gender dimension. There are several approaches to measuring: the poverty line approach, capabilities approach and the participatory poverty 
Socio-economic and political factors related to female labor force and decision making power in Bangladesh

approach. The poverty line approach separates the poor from the non-poor (Kabeer, 2003). Through the capabilities approach individuals can explore their personal circumstances and overcome social constraints. Participatory Poverty Index (PPI) emphasizes visual techniques, metrics, mapping, and diagrams to analyze poverty. It assumes that gender discrimination is innate and biologically driven.

Chapter Five relates gender inequality with poverty and its effects on household livelihoods. In South Asia (India, Bangladesh) male farming systems is a major means of livelihood; whereas in Sub-Saharan countries female farming systems are the main components of the economy. Regions with male farming systems usually have more patriarchal households while those dominated by female farming systems have more egalitarian households. Rural poverty in South Asia is connected with landlessness, rural wage labor and the caste system (Kabeer, 1995). Many poor women are forced to migrate to urban areas in search of employment. This makes them vulnerable to exploitation in terms of wage differentials and abusive and unsanitary conditions.

Chapter Six of the book deals with 'gender equality and human development outcomes; that is, enhancing capabilities'. Human capabilities are associated with education. Female education reduces women's fertility rates as women are more aware of and have access to contraceptives. Gender equality is the achievement of equivalent well-being between women and men, boys and girls. This equality rationale is the issue of mainstream social justice. Higher levels of maternal mortality rates are found in the lower income groups. This chapter indicates that there is a strong relationship between mothers' level of education and child mortality, contraceptive use and health care.

Chapter Seven of the book focuses on gender equality and women's empowerment, which is the third millennium development goal. Naila Kabeer (1995) mentions the ways to achieve these goals are: closing the gender gap in education, equalizing wages and increasing women's participation in politics. The combination of these factors should contribute to women's agency and independence. It is well accepted that women's empowerment is possible through education, paid work and political participation.

Chapter Eight talks about institutionalizing gender equality goals in the policy process. There are several policy strategies developed such as the Poverty Reduction Strategy Paper (PRSP) which addresses gender equality and poverty reduction by national and international actors. Another strategy is the Gender Responsive Budget (GRB) which promotes greater transparency in the policy process for interests of gender equality. These strategies are important in gender equality analyses because in extreme patriarchy, economic growth fails to address gender discrimination; and even women's working conditions continue to deteriorate and remain insecure.

\section{Book Summary: In Quest of empowerment: the Grameen Bank's impact on women's power and}

\section{status by Ainon Nahar Mizan (1994)}

The study presented in In Quest of empowerment: the Grameen Bank's impact on women's power and status by Ainon Nahar Mizan (1994) documents the result of an investigation into the effects of women's economic participation and earnings on their marital decision making power, that was carried out in rural Bangladesh. The author researches the Grameen Bank (GB). This Bank extends credit without collaterals to rural landless women in order to generate cash income and improve their economic conditions. It helps to create self-employment and contributes to the empowerment of women. The research examined the effects of rural work and income of Bangladeshi woman on her marital decision making power from the theoretical perspective of family sociology.

Chapter Two of Mizan's book deals with the demographic, socio-economic and cultural patterns of women's status in Bangladesh. In 1994 Bangladesh had a population 113.9 million people. More than half of the rural population was female. Of the 28.5 million civilian labor forces only 2.3 million were women. The majority of the population in Bangladesh is Muslim. Sons are highly valued in Bangladesh because they perpetuate the lineage and provide labor and income for the family. Rural women are confined to household work and have no 
Rouf, K. A.

decision making power in the family. Their work is invisible in the society.

Chapter Three reviews the sociological literature on women's economic participation and family decision making power to identify the gaps and problems between the two social aspects. Mizan analyses the concept of power, and its dynamic power relationship in the family decision making process from both an ideological and pragmatic point of view. She analyses these concepts pulling views from some sociologists like Max Weber, Blau and Szinovacz. To draw a concrete conclusion on the impact of the GB on its female borrowers Mizan incorporated Blood and Wolf's Resource Theory which examined how resources of the spouses became effective in determining their levels of power in the family.

The actual design, methodology is described in chapter four. The study was conducted in 1988 in two villages of Bangladesh. $100 \mathrm{~GB}$ female borrowers have interviewed, 50 women from each village. For comparison, an equal number of non-GB women borrowers were interviewed from the same villages. This was done in order to compare the differences in families of those not working and those engaged in income generating activities.

Chapter Five presents the major findings on household decision making power, fertility control, health care and political participation. The findings indicate that household decision making power by GB borrowers was significantly higher than non-borrowers. GB loans were successful in creating income generating activities for women in the informal sectors of the economy.

The final chapter examines the theoretical and policy implications of the factors determining women's power. The two major implications of the findings in this study are that they are related to either family or to social policies of Bangladesh. Norms and social context essentially define what a wife's resource is and what it is not. In this sense Blood and Wolf's theory is not enough to account for marital power in different social contexts. In rural Bangladesh, norms and role expectations determine the position one holds in the family and society. So resource theory alone does not provide a full expectation of women's marital power.

\section{Part B: Analysis of the Books' Themes}

Institutional rules, norms, and conventions have powerful material effects on people's life (Kabeer, 1995). These are varied based upon standards of the family, community and society, influence gender division of labour (productive versus reproductive) and participation in economic activities by women and men. The influence of patriarchy results in lower rates of female labor force participation. Figure 1 Women are forced to operate silently with male authority both in the home and outside (Kabeer, 1995; Mizan, 1994).

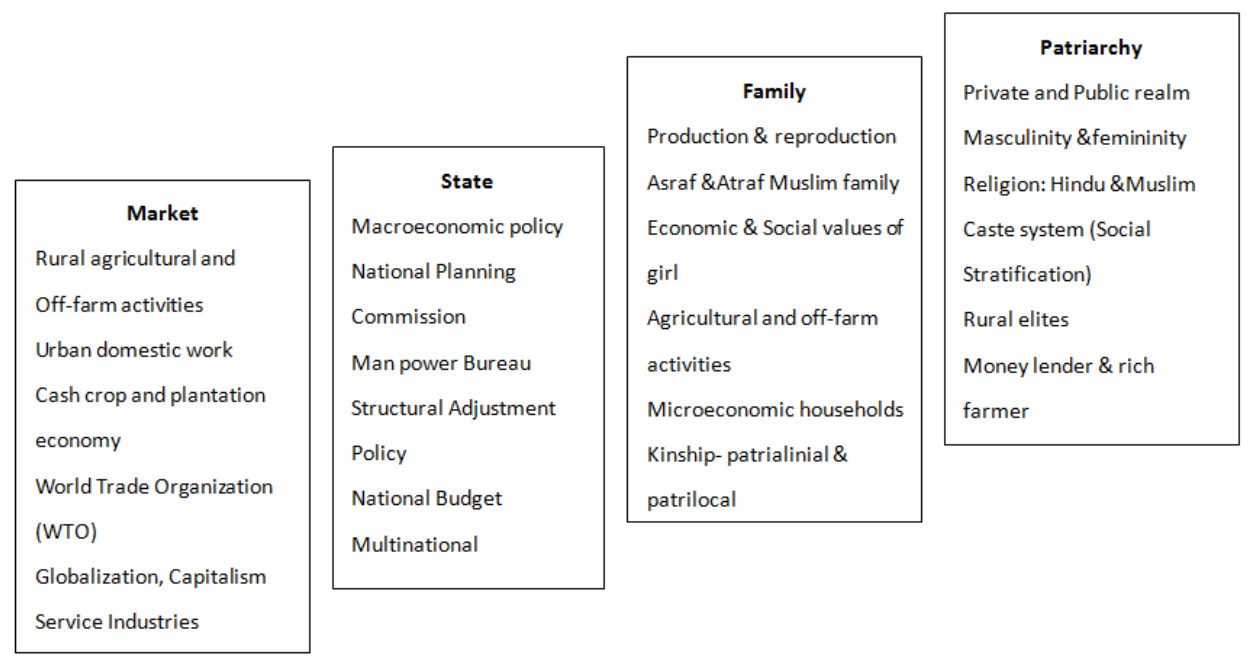

Figure 1. Institutions Related to Female Labor Market 
Socio-economic and political factors related to female labor force and decision making power in Bangladesh

Different institutions like states, markets, civil society/community and kinship/family determine the processes of production and reproduction, distribution of resources within a society and are influenced by patriarchy (Kabeer, 1995). For example, the state is responsible for the general leadership of society and different gender rules are determined and executed by it. Markets are based on the idea of "maximization of profit" and resources are exchanged through contractual entitlements. Maryling Waring (2001) asserts that kinship/families are the forms of social organization that includes clans that are based on descent, marriage and various forms of adoption. These institutions do not often work in egalitarian ways; instead they support hierarchical relationships which are dominated by patriarchy. There are biases and preconceptions in the household and community to allocate resources (Kabeer, 1995; Waying 2001). These biases result in inequalities of ownership or access to the means of production (land, capital, finance, and equipment) between men and women (Waying, 2001). Therefore, gender inequality is constructed through both formal laws and unwritten norms.

In the words of Naila Kabeer (1995), "[The] different rules, norms and values [that] govern the gender division of labor and the gender distribution of resources...are critical elements for understanding the nature of gender inequality in different societies" (p. 51). Instead of being directly involved in gender stereotyping, state or market institutions become 'bearers of gender'. They position women and men unequally in access to resources and assign them unequal value in the public domain (Kabeer, 1995 \& 2003). For example, in Seguino's study, findings show that gender inequalities in wages contribute to positive economic growth in patriarchal societies because social and political institutions support male power (Kabeer, 2003, p. 78). This positive synergy between economic growth and gender inequities in wages can be found in Hindu and Muslim dominated areas like India and Bangladesh, not excluding other regions.

According to Naila Kabeer (2003) gender is one of the key organizing principles upon which the distribution of labor, property and other valued resources in society are based. It exists everywhere in patriarchal society. Even NGOs treat women as dependent clients than active clients and banks refuse to lend to women entrepreneurs. The state treats women as second class citizens. That is why Naila Kabeer (1995) says, 'While institutional norms, beliefs, customs and practices help to explain the distribution of gender resources and responsibilities in different social groups" (p. 77). Patriarchy reinforces the interrelation of social norms that favor men and they create gender discrimination. For example, employers refuse to recruit women, discourage membership in trade unions and professional association.

Within the region of South Asia and especially Bangladesh, which is this paper's main focus, religion is a major factor in creating and maintaining gender inequalities (Figure 2).

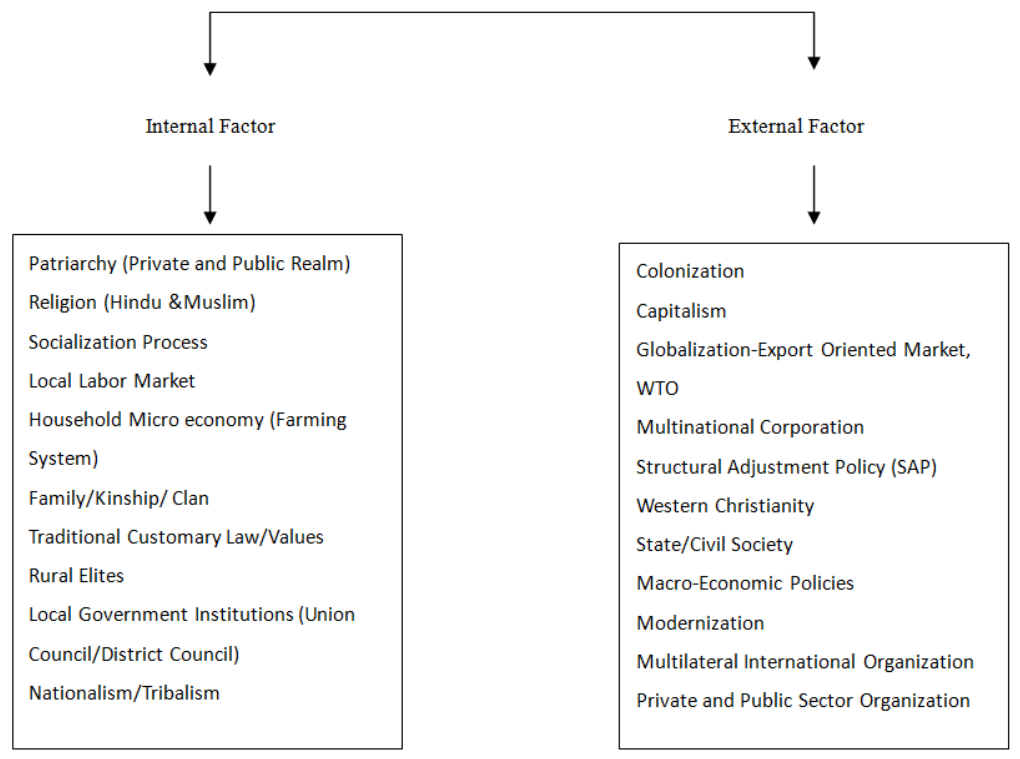

Figure 2. Gender Inequality in Bangladesh 
As seen in Mizan's book, the country is mainly divided between the Hindu and Muslim sects and these two systems serve to sub-serve some category of women. Hinduism is based on a caste system, which discriminates against women of lower and poorer castes. Islam on the other hand, relegates women into the private sphere, in light of the practice of purdah which states that the woman's place is in the home or extends so far as her husband or male superior approves. As a result of these practices these women are either confined to household reproductive labor or to the limited informal sector where they are more prone to exploitations.

Mizan's (1994) research findings on Resource Theory shows that loans and other financial resource has positive impact on poor women's self-employment and income as well as productivity-whatever little they earn contributes to the increasing household and per capita income (Mizan, p. 79). Resource opportunities for women lead to an emphasis on competence and achievement. In this context achieved resources of the spouses become effective in determining their levels of power in the family. In addition, to decrease Islamic religion's depressing effect on women's decision-making power, some local practices of Islam that have negative impact on women's status should be dispelled.

Women in Bangladesh have different experiences from men in regards to labor force participation. There are two major factors connected to this issue: (1) the under-representation of females in economic sector (market economy) and (2) the overrepresentation of women in the informal labor market. The impact of patriarchy extends into inequalities in labor force participation by members of both genders. Gender inequalities in the market means that women's labor is not calculated accurately or not recognized. The market and state do not provide resources to women for their equal participation in the labor market. Women are doubly disadvantaged in terms of their sex as well as that they have two main areas of responsibility while men have only one. Their time is divided between the household and the workplace. Women must carry out many tasks ranging from child care, food preparation, agricultural works, cleaning, and services to husband and all other domestic chores. In Bangladesh women work $10 \%$ longer than men but only $35 \%$ of their work is counted in National Accounts (Kabeer, 2003, p. 74). 50\% of women's work time goes into unpaid family labor in agricultural production among middle income families (Kabeer, 2003). These informal aspects of female labor are excluded from the national economy.

Despite their exclusion from income calculations, rural women in Bangladesh have always been active in both 'income generating' and 'income conserving' production. Naila Kabeer (2003) gives the example of a myriad of agricultural activities such as reaping and crop preparation that is carried out by these rural women which is a major contribution to the agricultural economy in their regions as well as to the whole country. These activities unfortunately also remain invisible.

Women's pattern of works in recent decades has experienced change. There has been a rise in the percentage of women in the labor force and an accompanying increase in their share of overall employment (Kabeer, 2003; Maring, 2001). For example, women's participation in manufacturing and service industries like tourism, garment, plastic industries and other manufacturing works have increased more rapidly than men's in India and Bangladesh. Women are also becoming increasingly involved in export sectors of market economies. In some regions women comprise $60 \%$ of this sector of the economy (Kabeer, 2003, p. 69).

Unfortunately, the characteristics of the new forms of labor (garment, fruits, vegetables and flowers packaging) in the formal employment results in different forms of exploitation from outworking, contract work, casual labor, part time work and home-based work (Kabeer, 2003). Women in these areas are usually grossly underpaid, forced to work for very long hours with forced overtime, have poor living conditions and often exposed to hazardous work environments leading to sickness. According to the MSN Resource Centre, women comprise $85 \%$ of the workforce in the garment sector, earning an average of US $\$ 1.54$ per day. This industry is very age restrictive as employers tend to favor women up to the age of 35 . Women outside of this group face severe discrimination, and are liable to lose their jobs. Within these areas of production women's jobs are highly insecure, devoid of pensions, no household or health benefits and there is almost no possibility of advancement. 
The situation for men in the economic sector is the adverse of women. Men generally make more than the women in the market. They have more opportunities available to them. They are able to travel as the rules of purdah do not apply to them but are rather controlled by them. They usually have higher levels of education, and therefore are not restricted finding work in the informal or the agricultural sector. In the factories for example, it the men who are the overseers and the supervisors while the women are the main labor force.

Another aspect of exploitation of female labor comes in the form of SAPs which are used by the IMF and the World Bank. This export oriented market through globalization and SAP has negative effects on the female labor market because of changes in the technology of transportation, telecommunication and dismantling of the regulatory frameworks of national and local markets for labor and capital. SAPs create newly poor in developing countries and increase the invisibility of women's involvement. Women are concentrated in lower skilled and lower paid jobs because of fast changing technology (Kabeer, 2003). SAPs put pressure on women to work more in factory related industries for minimal earnings. Therefore, women are victims in this globalization processes because society continues to invest less in women's skills development.

The migration of poor women to urban areas in search of employment has been increasing in Bangladesh. This is in response to the limited availability of both agricultural and off-farm paid work. However, this move to urban areas requires some mobility skills, financial capital and other technical skills (Figure 3).

\begin{tabular}{|c|c|c|c|c|}
\hline Country & $\begin{array}{l}\text { The gender distribution of } \\
\text { work in rural areas }\end{array}$ & $\begin{array}{l}\text { Household poverty \& } \\
\text { women's paid work in } \\
\text { rural areas }\end{array}$ & $\begin{array}{l}\text { Gender \& work in urban } \\
\text { areas }\end{array}$ & $\begin{array}{l}\text { Household poverty and } \\
\text { women's work in urban } \\
\text { areas }\end{array}$ \\
\hline India & $\begin{array}{l}\text { Landless poor in lower } \\
\text { cast in both off-farm } \\
\text { activities such as } \\
\text { non-agricultural wage } \\
\text { labor and high female } \\
\text { labor force participation } \\
\text { in agricultural waged } \\
\text { labor. }\end{array}$ & $\begin{array}{l}\text { Women from landless } \\
\text { and land-poor } \\
\text { households have the } \\
\text { highest participation in } \\
\text { paid work } \\
\text {-women combine paid } \\
\text { and unpaid work with } \\
\text { domestic chores }\end{array}$ & $\begin{array}{l}\text {-Workers in the organized } \\
\text { sector are mainly high } \\
\text { caste, skilled male } \\
\text { workers } \\
\text {-poor women are in the } \\
\text { informal economy } \\
\text {-women's participation in } \\
\text { the urban labor force is } \\
\text { lower than men's and that } \\
\text { also exist in rural areas. }\end{array}$ & $\begin{array}{l}\text {-women are involved in } \\
\text { low paying, low skilled } \\
\text { jobs } \\
\text {-lowest paying home } \\
\text { worker and the informal } \\
\text { economy which is most } \\
\text { women are involve in }\end{array}$ \\
\hline Bangladesh & $\begin{array}{l}\text {-growing landless, } \\
\text { declining farm size } \\
\text {-off farm activity such as } \\
\text { construction, trade, } \\
\text { transport } \\
\text { Female labor force } \\
\text { participation remains low }\end{array}$ & $\begin{array}{l}\text {-Greater poverty in } \\
\text { households with female } \\
\text { wage earners because } \\
\text { their husband's income } \\
\text { is in sufficient or due to } \\
\text { death, sickness etc. }\end{array}$ & $\begin{array}{l}\text {-A rise in females living } \\
\text { in urban areas } \\
\text {-poor women migrate to } \\
\text { the city to earn a living } \\
\text { mainly in exports such as } \\
\text { the garment industry }\end{array}$ & $\begin{array}{l}\text {-gender segmentation in } \\
\text { the informal economy } \\
\text {-women worked in the } \\
\text { garment factories while } \\
\text { men worked in skilled } \\
\text { crafts, transport and } \\
\text { service (Kabeer, 2003) }\end{array}$ \\
\hline
\end{tabular}

Figure 3. Gender inequality, women labor and household poverty in South Asia

These unskilled poor women are at an extreme disadvantage as they do domestic work, often living in with employers and have very low wage, work long hours which may be detrimental to their health. Family wage is another example of inequality that continues to be a reality for women today because women continue to receive lower wages for the same work. The original idea behind this was that men would support the family and women would not work outside the house. If they did work, it is argued that they would receive lower wages because they do not have the responsibility of supporting the children. In Bangladesh women may receive as little as half the wage that a man receives for doing the same job. Patriarchy has positive relationship between gender inequities in wages and rates of economic growth.

Furthermore, women and men may have different hierarchical positions in the marketplace. There are large numbers of women in the formal economy although they are underrepresented at the higher levels and 
over-represented in those lower down. For example, women in South Asia, a region with extreme patriarchy continue to be concentrated in unpaid family work (over $60 \%$ of the female work force) while in sub-Saharan Africa percentages of women in unpaid family work is generally below 60\%" (Kabeer, 2003, p. 72). So it is indeed a tragedy for women who have unequal access to economic opportunities in the labor market.

The household structure to which a woman is exposed may affect the extent to which she participates in the labor market and how this participation may in turn impact her power and position in her household. There are four types of household structures to be considered: joint families, nuclear families, corporate households and segmented households (Figure 4).

\begin{tabular}{|} 
Family Structure $\quad$ Extended family \\
Nuclear Family \\
Corporate Family (Male Farming) \\
Segmented Family (Female Headed Farming) \\
De-Jure Female Headed Household \\
De-facto Female Headed Household
\end{tabular}

Figure 4. Family Structure

Family structure places men at the head of the household in decision making for the family. In Bangladesh male farming systems are prevalent. Therefore, men make up the majority of the agricultural labor force. These households would then tend to be completely dominated by the husbands who would make most of the important decisions, and would control all the resources. In comparison female farming systems, which are found mainly in regions of Sub-Saharan Africa, are those systems in which the females dominate in the agricultural sector and have much more egalitarian and self-sufficient positions within their households (Kabeer, 2003).

The corporate and segmented households are connected to these two types of agricultural systems. In the corporate family structure men own most of the household's material assets control the labor of women and children and determine women's relationship with non-familial world. On the other hand, in the fragmented family structure men and women have separate but interdependent responsibilities in production, and separate but interdependent objectives to their families. Within segmented households men and women combine their income and an egalitarian household structure exists. Corporate households are related to regions such as Bangladesh where men are the absolute heads, who are involved in the formal market economy; while segmented structures are found mainly in Sub Saharan Africa where both spouses contribute towards household income.

Joint and nuclear family settings exist in Bangladesh but the nuclear family is increasing. In the nuclear family specific gender roles are assigned to the husband and wife. It is not a natural organization. In the 'ideal' nuclear family, the women are the caregivers, breeders and domestics; while men are the breadwinner. It is the source of gender inequality. Here men and women are differentiated by the division of labor. The emergence of the nuclear family is a consequence of complex interactions between male power and a capitalistic society. Gender division of labor creates a power difference between women and men. It adds to the subordination of women. As a result, women are dependent on men for economic support. However, in the joint/extended family women have more egalitarian positions in the agricultural society although men and women have some responsibility both inside and outside the home. This egalitarian extended family values has changed by introduction plantation and cash crop economy. Men have more power and privileges in the labor market in the nuclear family.

Different findings show that increasing the wage of wives has significant positive impact on their economic status as well as the whole household. In addition, wife's income contribution enhances her position in the 
Socio-economic and political factors related to female labor force and decision making power in Bangladesh

family and increases her power in decision making. It especially in the areas of fertility control decision about how many children to have. Mizan's study findings (1994) acknowledged a wife's income gives her leverage in power relations in the family due to her breaking away from the traditional roles of housewife and child bearer to enter the provider role.

Anon Nahar Mizan (1994) study on Grammen Bank finds that women's dependency on male members is getting reduced and there is emerging a new pattern of relationship in their households and in the society as they are growing earning members. They are not only gaining economic independence but are also emerging as a social force to fight away all prejudices and obstacles (Mizan, p. 23). Orthodox economic thinkers still have biases that produce constraints to policy makers in developing effective poverty reduction strategies through the concepts of price stability, marketization, commodification, and the male bread winner (p. 212). They never think gender equality in labor force participation in the market. So in macroeconomic there is no gender equality rather more discrimination exists against women in employment, gender specific role. For example, women do secretarial jobs, men do construction jobs.

Conservative policy makers treat human resources as natural resources. They generally think that a reduction of men's poverty would automatically reduce poverty in women. Women's earnings are considered secondary and so priority is given to the primary breadwinner, men. However, households are not egalitarian and there major inequalities in the distribution of basic needs (Waring, 2001). Therefore, women and children may not benefit from an improvement in the improvement in the man's economic condition. To make macro-economic policies more gender aware, it needs to understand women's contribution in production and reproduction. Therefore more attention needs to be paid to the micro economic sector of the family which is the key institution of the reproductive economy; and where women make major contributions.

Although in Millennium development goals poverty reduction has taken a central place in development effort and pro-poor growth; however, gender equality is still not the first priority in MDGs (Kabeer, 2003). Although there are several development polices and strategies that have been developed with the help of international agencies to address gender and poverty; this paper will pay special attention to Poverty Reduction strategy Papers (PRSP), Gender Responsive Budgets (GRB), Sectoral Strategy for Poverty Policy (SSPP) and Gender Management System (GMS) that are used in macroeconomic policy (Figure 5).

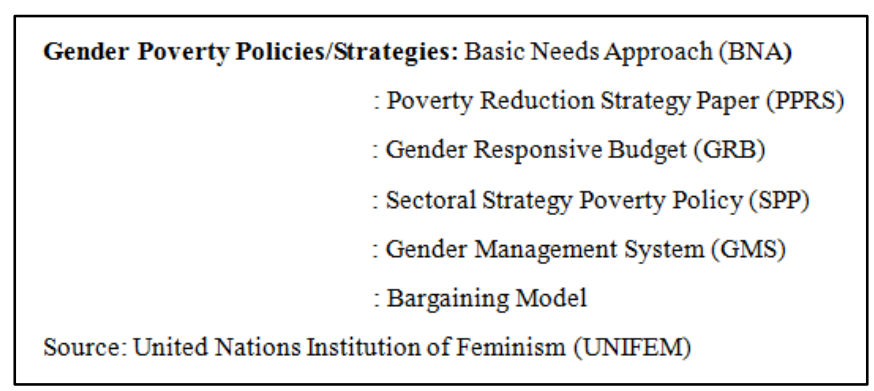

Figure 5. Gender Poverty Policies/Strategies

The poverty reduction strategy paper (PRSP) audits the gender activities and reviews the role of gender responsive budgets (GRB). PRSP deals with a country's macro-economic structural and social policies and programs to promote economic growth and reduce poverty and to identify external financial needs of a country (Kabeer, 2003). It examines the role of the institutionalization of gender competences in the policy process. However, it does not consider gender inequality which has negative effects on household livelihood. Although PRSP explore opportunity for gender mainstreaming and poverty reduction, it has not however, become an integral component of aid-cooperation agencies but rather, is heavily influenced by the World Bank and IMF and grown reliant on external technical advice. Although the gender issue in PRSP is better integrated in health, nutrition, population and education sector, it is vague because if gender issues not brought up at the diagnostic stage, it is unlikely appear in the action or monitoring stages (Kabeer, 2003). PRSP policy design was studied in 
Burkina Faso, Gambia, Vietnam and Kenya. The studies identified low levels of productivity in farm and off-farm activities where there was an imperfect market for goods and services which contributes to rural poverty. Unequal educational opportunities held back women's employment in the modern labour market (Kabeer, 2003). It expands global rules of trade and global market expansion regulated by bi-lateral and multilateral trading agreement, tariffs and non-tariffs barriers. These barriers cost $\$ 100$ billion a year, twice as much as they receive in international aid (Kabeer, 2003, p. 211). PRSP pays little attention to women's role in reproductive economy, voice and influence on macroeconomic policies. Issues like domestic violence and political education are not considered to be relevant to poverty reduction strategies.

The Sectoral Strategies for Poverty Policy (SSPP) are used by macroeconomic policy makers. This strategy emphasizes key opportunities and constraints within and across sectors because there are interconnections between mezzo and micro level analyses of household strategies with macro level analysis. However, it is a question of sectoral priority for resource allocation to poor, disadvantaged women because women are at a greater disadvantage in their reproductive well-being which is culturally discounted within the family.

The Gender Responsive Budget (GRB) is also called the gender sensitive budget (Kabeer, 2003). It aims to assess the impact of government budgets mainly at the national level for different groups of men and women. It analyzes gender-targeted allocations, expenditures across all sectors and services and reviews equal allocations of expenditure within government services (Ibid, 2003). GRB analysis plays a number of different roles in promoting greater transparency in the policy development process and strengthening accountability. It intends for government expenditures to target women and to promote gender equality. However, gender commitments are backed by financial resources and are tied to PRSP technical cooperation aid. GRB does not interfere with location-specific variations on gender inequality issues at the micro level.

Although gender equality exists in MGD, however, still some barriers exist in the mainstream society. For example, lack of political will, under funding and marginalization in women affairs, and institutionalization of patriarchal intent and deep rooted resistance in budgetary allocations. To avoid the above barriers on policies of gender equality the Common Wealth Secretariat developed Gender Management System (GMS) tools for maintaining gender in policy making. GMS is a set of concepts and methodologies built to develop network structures, mechanisms and processes that are intended to develop policies, plans and programs for women and to provide comprehensive gender inequality analysis. However, the success of gender mainstreaming requires a review of national development plans. GMS is intended to bring fundamental and lasting change in society but it starts organizational change at the government level; which is a shortcoming because change requires gender awareness strategies at the grass roots level to change the formal and informal norms, rules and attitudes that institutionalize inequalities.

Lack of gender expertise in policy making bodies adds to a lack of consultation with primary stakeholders. This can be effectively addressed by building up active and organized constituencies at the grass root levels through consciousness raising to exercise pressure for gender equality goals and to hold governments and states accountable for their action or inaction (Kabeer, 2003). In Bangladesh some NGOS like Narri Pakka and Nijera Korri started to monitor government services delivery at the local level despite their minimal influence. UNIFEM played an important role to bring civil society together to promote GRB analysis. It seeks to empower women and women's organization to influence budget decisions and advocate for women's equality by building their technical budget expertise (Kabeer, 2003). However, UNIFEM is an international external resource organization that is not always available to support all countries. Therefore, national gender budget experts are necessary for mobilizing gender equality goals and national gender action plan through collective action by women advocacy group.

Gender equality in labor markets, access to services, household economics and in policy process is not a linear one because patrilineal oppression and dominance is still very much embedded in every aspect of society. It is the achievement of women's movement and other activities in different countries. All these activisms have 
Socio-economic and political factors related to female labor force and decision making power in Bangladesh

positive implication in closing the gender gap in women's health services and education. It starts to count women's role as visible in the national economy; however, the concern still remains to engage institutions more directly with the policy process through gender activism. Therefore the major challenge is for gender advocates and activists in the 21 st Century to form alliances with others for seeing equitable international order to ensure that gender equality interests remain at the forefront of the struggle (Kabeer, 2003, p. 233).

Another recommendation involves increasing women's waged employment in the non-agricultural sector and to secure land tenure because a working wife bringing valued resources and income into the family is expected to gain a significant increase in decision making power relative to her husband and have more power than non-working wife. It is hoped that with the change in women's income, employment and education there will be other opportunities to change the extremity of patriarchal influence over women. Anion Nahar Mizan says (1994) that when both partners contribute equally to their mutual satisfaction then they have egalitarian power in the family.

The Grameen Bank has also been extremely instrumental in providing income generating opportunities to women and in their overall empowerment through the extension of collateral free banking to rural poor women in Bangladesh. Women's participation in Grameen Bank results in their increased outside participation which increases their physical and social mobility. This will positively affect their role and position in society. However, there is still a great need for the government to reform labor market policy and introduce affirmative action to promote labor market equality and ensure women's access to productive resources, mobilize efforts to break the patriarchal dominance in the labor market and alter economic and institutional arrangements to promote more choices to women (Kabeer, 2003; Waying, 2001).

\section{Conclusion}

In all three books, by Kabeer, Marying and Mizan, the critically disadvantaged situation of Bengali women is examined. These females are doubly disadvantaged in both poverty and gender. The writers also agree, as has been presented in this paper that these women may be empowered and their socio-economic and political conditions improved through the continued and increased work of NGOs and the restructuring of decision-making, policy development and increased opportunities for formal labor market participation. One concrete example can be found in Mizan's study where she concludes from her findings that the creation of social welfare mechanisms especially micro-lending seems to be a highly successful means of bettering the conditions of the rural poor and overriding the conditions that create poverty. Gender equality is threatened by male power and privilege of policy makers. It is therefore the opinion of this author that it is imperative that the elements of patriarchy be dismantled through rethinking and restructuring of policy making before any major changes towards gender neutrality can occur.

\section{References}

Kabeer, N. (1995). Reserved realities-gender hierarchies in development thought. London, Great Britain, Biddles Ltd.

Kabeer, N. (2003). Gender mainstreaming in poverty eradication and the millennium development goals. Ottawa: International Development Research Center (CIDA). http://dx.doi.org/10.14217/9781848598133-en

Mizan, A. N. (1994). In quest of empowerment: The Grameen Bank's impact on women's power and status. Dhaka: The University Press.

Waring, M. (2001). If women counted. Ottawa: National Film Board of Canada (NFBC).

Wong, W. A. (2002). The poor women- A critical analysis of Asian theology and contemporary Chinese fiction by women. New York: Peter Lang. 
Rouf, K. A. 